\title{
Improvement of Seed Quality and Stimulated the Growth of Brown Rice with Matriconditioning Plus Plant Growth Promoting Rhizobacteria (PGPR) agents in Jatiluih Tourism
}

\author{
I. Made Sudana*, I. Gusti Ngurah Raka and Ni Luh Made Pradnyawathi \\ Faculty of Agriculture, University of Udayana, Indonesia \\ *Corresponding author
}

\section{Keywords}

World cultural heritage, Jatiluih brown rice, Organic farming, PGPR bacterial matrix, Biofertilizer

\section{Article Info}

Accepted:

22 July 2020

Available Online: 10 August 2020

\section{A B S T R A C T}

Jatiluih Village is a cool, mountainous area in Penebel sub-district, Tabanan regency is a World Cultural Heritage area (World Herritage). This area is visited by many foreign tourists and is one of the famous tourism areas in Bali. The tourism object in this area is the natural beauty of terraced rice paddies and in the paddy fields there are many cowshed as a source of organic fertilizer, accompanied by a strong survival system of irrigation culture called Subak. The famous rice production in this area is brown rice, Jatiluih local brown rice is very popular with urban communities because besides it is organic, it also tastes fluffier and fragrant but if it is cooked it doesn't need to be mixed with white rice. Thus the improvement of brown rice cultivation should be carried out by involving growth-promoting bacteria (PGPR) whose application is to seed treatment in the proper carrier matrix, from the results of research obtained; A matrix containing with one PGPR bacterium can increase seed germination capacity, and brown rice plant height compared to control without PGPR. Organic fertilizer in the form of a matrix containing 4 types of bacteria Serratia marcescens, Achromobacter spanius, Providencia vermicola and Myroides adoratimimus can increase seed germination by 2 times, plant height and number of plant leaves 1.5 times compared to control. In terms of Stimulated the growth of rice plants, between the PGPR bacteria, it turns out that $A$. spanius and $P$. vermicola bacteria have a fairly good ability to increase the number of tillers in rice plants by 1.5 times the control, and it is expected that later production of brown rice will increase to 1.5 times as well. Likewise, rice plants that received PGPR bacteria produced higher, higher number of leaves and chlorophyll compared to controls that did not get PGPR bacteria. In the chromatographic image the GCMS results clearly showed the content of the compounds in the control ie plants without being given PGPR, the number of compounds was far less than in rice that was treated by PGPR bacteria. Rice with PGPR contains 9, 12,15 -Octadecatrienoic acid which is anti-bacterial and anti-fungal, while Neophytadiene and 2-Methoxy-4-vinylphenol can increase plant growth.

\section{Introduction}

In the context of developing tourism objects in Bali, it is necessary to increase the development of tourism objects in rural areas so that the tourism cake can also be enjoyed by residents in rural areas. Jatiluih is a mountainous area with a very beautiful view 
because there are many terraced rice fields, with this terraced rice field system, the village of Jatiluih is crowned by UNESCO as a world cultural heritage (World Herritage). Because it has been designated as a world cultural heritage, more and more foreign and domestic guests are visiting this area because in addition to the beautiful nature, friendly people, and the community is still strong in maintaining agricultural traditions and ancestral cultural customs in the area.

In carrying out their agricultural activities, the Jatiluih people still carry out Tri Hita Karana which has been applied from generation to generation and farmers in this village are still implementing traditional equipment in their fields, for example in Plowing rice fields using cattle labor as well as a cow manure source of organic fertilizer, cowshed that appear in rice fields add to the more beautiful and beautiful rice fields in Jatiluih.

In the application of Tri Hita Karana in the endeavored the existence of a balance of relations between humans and nature, namely rice fields and their ecosystems, humans and humans and humans with God as creators. So that in planting rice, starting from seeding, securing, irrigating, maintaining, controlling the plant-disturbing organisms to being inseparable from religious rituals, ask God to succeed in planting and then thank you for the abundant harvest at Batur Temple in the Subak location (Saputra et al., 2017). This situation will also be a tourist attraction that is very popular with foreign guests

The superior product in the village of Jatiluih is the local brown rice Jatiluih, according to farmers in the village of Jatiluih, this brown rice has been cultivated since the Dutch era and even in the notes in the "Lontar" said it has been since 1000 years ago, so it is not surprising that this brown jatiluih rice has a characteristic odor, distinctive color and taste and much different from other regions brown rice. In urban areas, brown rice is highly sought after by consumers because they know that jatiluih rice is rich in nutrition and healthy because it is cultivated organically, so the price can reach Rp. 20.000-25.000/ kg.

However, the production of brown rice by farmers is still very low, this is in addition to several types of jatiluih red rice, there may be some that are less superior, also because in carrying out organic rice farming activities can not be done optimally by farmers for example in the manufacture of organic fertilizers and pesticides, as well as the use of poor quality brown rice seeds, poor maintenance of seedlings and poor For this reason, this Innovation research activity will select the most superior types of brown rice Jatiluih both in terms of quality and productivity, as well as its expertise in planthopper pests and Tunggro disease. Furthermore, this superior brown rice will be developed to obtain organic farming technology suitable for the brown rice. It is hoped that this superior red rice will be informed to farmers to be developed organically and include an organic farming technology package suitable for that rice

\section{Materials and Methods}

\section{Matriconditioning with active ingredients rhizobacteria plant}

\section{Growth Promoting Rhizobacteria (PGPR)}

\section{Matrix formation in the form of flour as biofertilizer in brown rice plants}

Formulation work is done by inoculation the PGPR microbes on Potato Peptone Glucosa media in the fermentor and incubated for 1 week, then microbial colonies are harvested by means of centrifugation at a speed of $10000 \mathrm{rpm}$, then the sediment is mixed evenly in a mixture of Milk and bentonite (2: 1) with 
bacterial concentrations $1 \%$ and dried to air dry using a blower, after drying the mixture is smoothed again to form a flour, then a biofertilizer is obtained ready to use.

\section{Formation of a matrix in liquid form as a} biofertilizer on the red rice paddy plant

Formulation is done by preparing the media must be organic with the formation procedure is as follows: boiled potatoes $30 \%$, then filtered, and filtered water plus $1.5 \%$ brown sugar and $1 \%$ peptone, then sterilized with an autoclave. After this stage is complete, the mixture is inoculated with PGPR Rhizobacteria and, then fermented using a biofermentor for 2 weeks and $\mathrm{pH}$ measurements are taken again. If the fermented biopesticide solution shows an acidic $\mathrm{pH}(1.0-5.0), 1 \mathrm{~m} \mathrm{KOH}$ is added to the solution with the aim of increasing the $\mathrm{pH}$ to 7.4. Then the culture mixed with Tween 80 as much as $1 \%$ to preserve microbes, then formed a biofertilizer with active ingredients PGPR

\section{Formation of matrices in the form of sand as biofertilizer in red rice plants}

Formulation is done by preparing the Atif sand media with the formation procedure is as follows; $500 \mathrm{~g}$ of Active Sand mixed with 10 grams of sugar and enough water. The material is mixed evenly and put in a plastic bag to be sterilized with an autoclave. After that, it was inoculated with $10 \mathrm{ml}$ of Rhizobacteria PGPR culture, stirred thoroughly and incubated at room temperature for 2 weeks.

Formation of Matrix in the form of Bioslury as Biofertilizer on red rice plants

The source of PGPR Rhizobacteria inoculum was prepared respectively in a liquid Potato peptone glucose (PPG) medium and incubated for 2 days until the media looked turbid and full of bacteria, then Bioslury media was prepared which was derived from waste biogas waste. Media Bioslury is packed in $250 \mathrm{~g}$ plastic bags each and $50 \mathrm{~g}$ wood charcoal flour, then sterilized using an autoclave. After the Bioslury media cooled, each medium was inoculated with $10 \mathrm{ml}$ of Rhizobacteria phosphate solvent culture. Next Bioslury media which has been inoculated with Rhizobacteria phosphate solvent incubated for 15 days, while every day the culture is stirred.

\section{Application of PGPR rhizobacteria matrix in red rice by seed treatment}

Before the rice seeds were planted in the plot of the experiment on the seeds applied PGPR Rhizobacteria by means of;

a. For PGPR Rhizobacteria in the form of flour, liquid and sand Rice Seed as much as $100 \mathrm{~g}$, mixed evenly on $200 \mathrm{~g}$ Sterile matrices in a moist state then stirred evenly in sterile plastic bags and incubated / imbibed for 24 hours, after which the seeds of Red Rice rice can be planted in a nursery.

b. For PGPR Rhizobacteria in the Bioslury Matrix, 100 seeds of red rice can be mixed with $200 \mathrm{~g}$, the Biofertilizer and seeded for 24 hours, after which the seeds can be planted in the nursery

Planting of red rice paddy seeds that have received PGPR matric conditioning treatment in the paddy field

The field research was carried out as the best PGPR Rhizobacteria adaptation test results in the laboratory and in the greenhouse, the purpose of which was to determine the stability of these microbes in stimulating the PGPR bacteria to form good roots in the red rice plants in Jatiluih village, but in this field research Rhizobacteria in first formulate it into biofertilizer using the method of 
Hanuddin et al., (2010), so that later biofertilizers can be commercially distributed to farmers and rice production will increase in production. The field research was carried out using a RAK research design using 5 replications, red rice rice varieties planted were local varieties, which have superior properties; The treatments tested are:

Research I, consisting of: (each Matrix carries 1 PGPR)

\section{PGPR Bacteria carrier Matrix:}

Matrix in the form of Flour

The matrix in liquid form

Matrix in the form of Sand

Matrix in the form of Bioslury.

\section{Rhizobacteria type PGPR that is able to} induce plant growth:

Rhizobacteria PGPR; Serratia marcescens from the roots of the black rice rice plant in Subak Slonding, Penebel Tabanan

Rhizobacteria PGPR Myroides adoratimimus from Paddy in Sanur

Rhizobacteria PGPR Achromobacter spanius from the roots of Jatiluih brown rice

Rhizobacteria PGPR Providencia vermicola from the roots of rice plants in the Maumere region of Papua

\section{Control treatment}

Brown rice is planted according to local farmers' habits. How to plant it does not give a biofertilizer matrix,

Research II, consisting of each matrix, brought 4 PGPR

\section{Matrix in the form of flour containing;}

Serratia marcescens Achromobacter spanius Providencia Vermicola Myroides adoratimimus
The matrix in liquid form contains; Serratia marcescens Achromobacter spanius Providencia Vermicola Myroides adoratimimus

Matrix in the form of Sand, contains; Serratia marcescens Achromobacter spanius

Providencia Vermicola

Myroides adoratimimus

Matrik in the form of Bioslury, containing;

Serratia marcescens Achromobacter spanius

Providencia Vermicola Myroides

adoratimimus

d. Planting

Brown rice seeds that have received Seed Treatment treatments with the PGPR Rhizobacteria Matrix are planted in the nursery in separate tubs according to the number of PGPR bacteria tested, up to the age of 21 Days. After sufficient age the seedlings are sown to be moved in a trial plot whose soil has been cultivated and is ready to be planted. Planted in the field with a spacing of $20 \times 25 \mathrm{~cm}$ in a plot of land that is processed with a depth of $15 \mathrm{~cm}, 2$ X $2.5 \mathrm{M}$ plot size, each planting hole filled with 3 seeds, and after growing sparsely planted into one plant per hole, plants are maintained well until harvest while being watched;

\section{Data observed for field experiments include}

\author{
Plant height $(\mathrm{cm})$ \\ When you exit panicle (hst) \\ Leaf area $\left(\mathrm{cm}^{2}\right)$ \\ Number of leaf chlorophyll
}

\section{Results and Discussion}

This first year research aims to determine the effect of 4 types of PGPR bacteria (Plant Growth Promoting Rhizobacteria), namely Serratia marcescens, Achromobacter spanius, Providencia vermicola and Myroides 
adoratimimus, which are formulated in the Flour Matrix, Liquid Matrix, Sand Matrix, and Bioclury matrix to stimulate rice growth. Organic Red rice and increase the resistance of rice plants to pests and rice diseases in the Jatiluih area as for the research results obtained are

\section{Seed germination after being applied by the PGPR Matrix}

Rice seeds, after being mixed with a matrix containing PGPR and being brewed for 24 hours, were tested for seed germination after receiving treatment (Table 2). In the table it appears that the PGPR treatment improves the quality of the seeds, because the germination rate increases compared to control. However, if seen from the biological fertilizer matrix it turns out that the matrix containing PGPR mixture (4 PGPR bacteria) has seed germination of $90 \%$ and above is the best treatment for developing organic rice in jatiluih, this is likely a matrix containing a mixture of PGPR bacteria (Serratia marcescens, Achromobacter spanius, Providencia vermicola and Myroides adoratimimus) can be used as seed treatments to get seeds ready to be planted in uniform growth fields and the use of seeds can be economized.

However, if seen from the influence of bacteria and the type of matrix it turns out that the Achromobacter spanius bacteria in the Compost and Sand matrix is active, resulting in germination of up to $89 \%$ compared to other single treatments. It is possible that these bacteria can increase plant growth hormones in rice seeds, and also provide Phosphate elements that can be absorbed by plants, because these bacteria are also a phosphate solvent in the soil

\section{Plant height brown rice}

After the seedlings were planted in the study plot, it can be observed the development of plant height (Table 2), the table shows that the treatment matrix containing PGPR bacteria increases plant height, which is between 80 $\mathrm{cm}$ to $85 \mathrm{~cm}$, while the control without matrix height of rice plants is only $69.84 \mathrm{~cm}$, so the addition of treatment height reached 1.5 times compared to control.

In table 2, it also appears that the matrix containing 4 PGPR bacteria, plant height appears to be higher than the matrix containing 1 PGPr, and tan compared to the control is 1.25 times higher, this indicates that the four bacteria are synergized to produce IAA growth stimulants or other hormones, and possibly also be able to provide phosphate and nitrogen for rice plants.

When viewed on PGPR singly in the matrix, it turns out that Achromobacter spanius in the Compost and Active Sand matrix causes plant height to be quite high compared to other single bacteria.

\section{Number of leaves of rice plants}

After being given a matrix containing PGPR bacteria, it turns out that the highest number of leaves produced by rice plants turns out to be a matrix containing 4

PGPR bacteria producing fewer leaves compared to other treatments, it turns out here it does seem that plants that are applied to 4 types of PGPR will not be able to increase growth rice plant leaves, because it appears that rice growth which is only applied with one type of PGPR bacteria is more fertile than being eroded as well as 4

PGPR bacteria this can be seen in Table 2.

In table 2 it appears that the flour matrix containing PGPR A. spanius and $S$. marcescens produced the fewest number of leaves compared to other treatments. The 
possibility of these bacteria produce fewer growth hormones than other PGPR bacteria

\section{Amount of chlorophyll leaves after being given PGPR bacteria}

In table 2, it appears that the PGPR bacterial uptake, between control and PGPR treatment, does not seem to differ much, possibly in the study area, the nutrient content of $\mathrm{N}, \mathrm{P}$ and $\mathrm{K}$, because the land where the research is very often planted red rice, so that when the Young plants do not appear to have symptoms of pale leaves, this is characterized by the formation of leaf chlorophyll going well because the land contains enough nitrogen. However, there is a tendency that $S$. marcescens may be able to increase the amount of chlorophyll in rice leaves.

\section{Number of tillers}

In table 1, it appears that the rice plant given by PGPR bacteria has more number of tillers than in the control without PGPR, here it appears that the possibility of PGPR bactri in addition to adding $\mathrm{N}$ and $\mathrm{P}$ nutrient elements in plants also produces growth-stimulating substances or ZPT to rice plants. It seems that PGPR bacterial inoculation combined with the same ability to spur the growth of rice plants. Between the PGPR bacteria, it turns out that $A$. spanius and $P$. vermicola bacteria have a fairly good ability to increase the number of tillers in rice plants by 2.5 times the control, and it is expected that later production of brown rice will increase to 2.5 times clay too (Table 1).

\section{Identification of compounds found in rice plants after being given PGPR}

From the results of observations of the effect of the administration of PGPR bacteria, it seems very striking that all plants receiving the PGPR treatment give better plant growth results than control, so it is clear that PGPR bacteria are able to stimulate plants to produce certain compounds that stimulate plant growth.

It also appears that plants that are treated with PGPR in combination with 4

PGPR bacteria, apparently vegetative growth is better than plants that are only given one type of PGPR bacteria, so it is possible that if the bacteria are combined, it will give a synergistic result to increase plant growth. For this reason, the chemical compound content was determined using GCMS equipment, which was carried out at the Bali Police Criminal Forensic Laboratory.

Before using GCMS equipment the chemical compound on rice leaves was extracted using Methanol, then 10 grams of rice leaves were immersed in $200 \mathrm{ml}$ of methanol, then macerated for 48 hours, then filtered the solution with filter paper then evaporated using a Rotary Evaporator, and brought to the Forensic Laboratory for know the types of chemical compounds contained.

The GCMS results obtained several different chemical compounds depending on the application of the PGPR bacteria, this can be seen in the KROMATOGRAPHY picture.

In the chromatographic image, it was clear that the compound contained in the control was given without PGPR plants, the number of compounds was far less than that of rice treated with PGPR bacteria. Rice with PGPR contains 9, 12, 15- Octadecatrienoic acid which is anti-bacterial and anti-fungal, (Ahsol Hasyim et al., 2017), while Neophytadiene and 2-Methoxy-4-vinylphenol can increase plant growth (Kartina et al., 2019). 
Table.1 Seed germination due to matrix treatment containing PGPR bacteria

\begin{tabular}{|c|c|c|c|c|c|c|}
\hline Matrix & PGPR bacteria & $\begin{array}{c}\text { Germinati- } \\
\text { on } \\
(\%)\end{array}$ & $\begin{array}{l}\text { High of } \\
\text { Plant } \\
\text { (cm) }\end{array}$ & $\begin{array}{l}\text { Number of } \\
\text { leaves }\end{array}$ & $\begin{array}{l}\text { Chlorophyll } \\
\text { (SPAD) }\end{array}$ & $\begin{array}{l}\text { Number } \\
\text { of tillers }\end{array}$ \\
\hline \multirow{4}{*}{ Flour } & S. marcescens & 81.00 & 74.14 & 37.37 & 26.57 & 8.06 \\
\hline & A. spanius & 66.00 & 59.82 & 48.48 & 27.01 & 12.48 \\
\hline & P. vermicola & 74.00 & 61.46 & 41.45 & 26.87 & 10.66 \\
\hline & M. adoratimimus & 75.33 & 76.77 & 39.12 & 26.46 & 8.86 \\
\hline \multirow[t]{4}{*}{ Liquid } & S. marcescens & 78.33 & 61.52 & 31.80 & 26.11 & 9.60 \\
\hline & A. spanius & 82.67 & 61.55 & 42.32 & 27.10 & 13.26 \\
\hline & P. vermicola & 86.00 & 60.64 & 41.14 & 27.51 & 11.32 \\
\hline & M. adoratimimus & 77.00 & 77.142 & 29.53 & 25.66 & 8.00 \\
\hline \multirow{4}{*}{$\begin{array}{l}\text { Active } \\
\text { sand }\end{array}$} & S. marcescens & 88.33 & 62.042 & 42.40 & 27.47 & 12.54 \\
\hline & A. spanius & 89.67 & 62.09 & 42.93 & 26.14 & 12.14 \\
\hline & P. vermicola & 89.00 & 64.40 & 41.48 & 26.44 & 13.34 \\
\hline & M. adoratimimus & 91.33 & 75.04 & 28.32 & 25.60 & 7.94 \\
\hline \multirow[t]{4}{*}{ Compost } & S. marcescens & 89.67 & 58.64 & 41.00 & 28.10 & 12.28 \\
\hline & A. spanius & 90.67 & 60.28 & 42.13 & 25.92 & 12.73 \\
\hline & P. vermicola & 89.67 & 56.22 & 40.53 & 27.44 & 11.66 \\
\hline & M. adoratimimus & 87.67 & 76.37 & 33.26 & 28.12 & 9.74 \\
\hline Flour & $\begin{array}{l}\text { Mixture of PGPR } \\
\text { Bacteria }\end{array}$ & 92.00 & 82.46 & 28.42 & 26.72 & 9.36 \\
\hline Liquid & $\begin{array}{l}\text { Mixture of PGPR } \\
\text { Bacteria }\end{array}$ & 92.67 & 85.96 & 37.80 & 27.82 & 11.02 \\
\hline $\begin{array}{l}\text { Active } \\
\text { sand }\end{array}$ & $\begin{array}{l}\text { Mixture of PGPR } \\
\text { Bacteria }\end{array}$ & 94.33 & 80.84 & 33.28 & 28.26 & 9.68 \\
\hline Compost & $\begin{array}{l}\text { Mixture of PGPR } \\
\text { Bacteria }\end{array}$ & 92.33 & 81.26 & 32.00 & 26.76 & 10.06 \\
\hline \multicolumn{2}{|l|}{ Control } & 69.67 & 69.84 & 24.64 & 23.36 & 7.98 \\
\hline
\end{tabular}

Chemical compounds, but the combined content of each compound is more than other bacteria

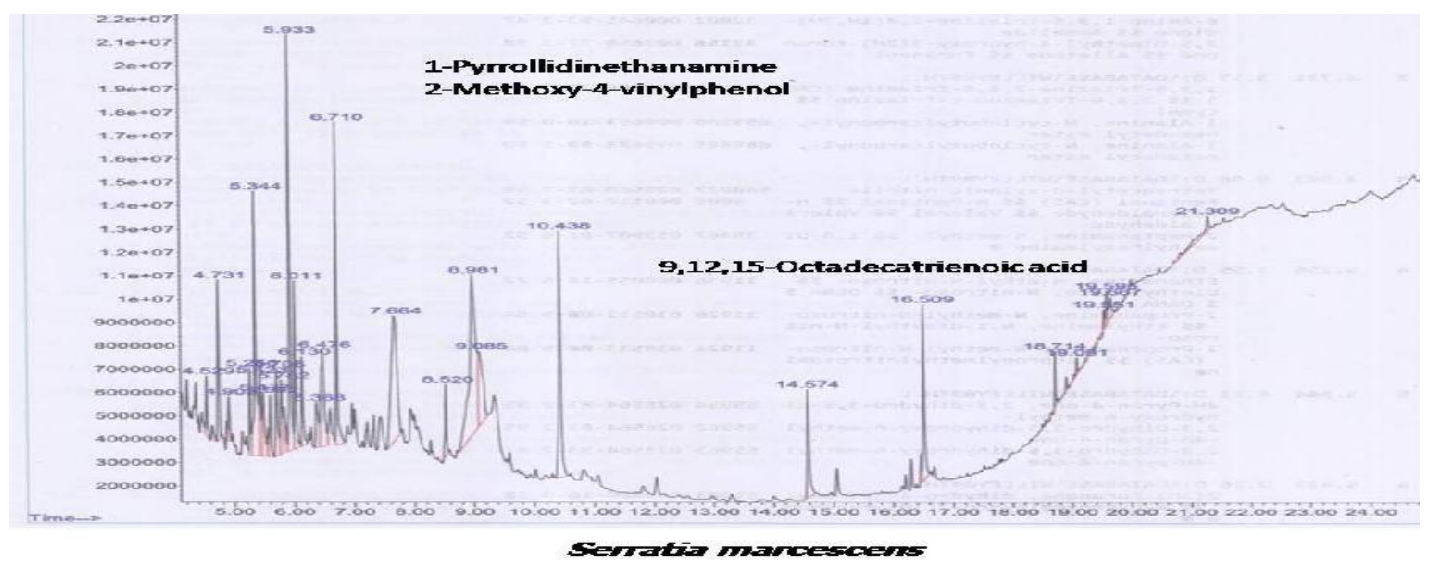


Int.J.Curr.Microbiol.App.Sci (2020) 9(8): 2788-2798
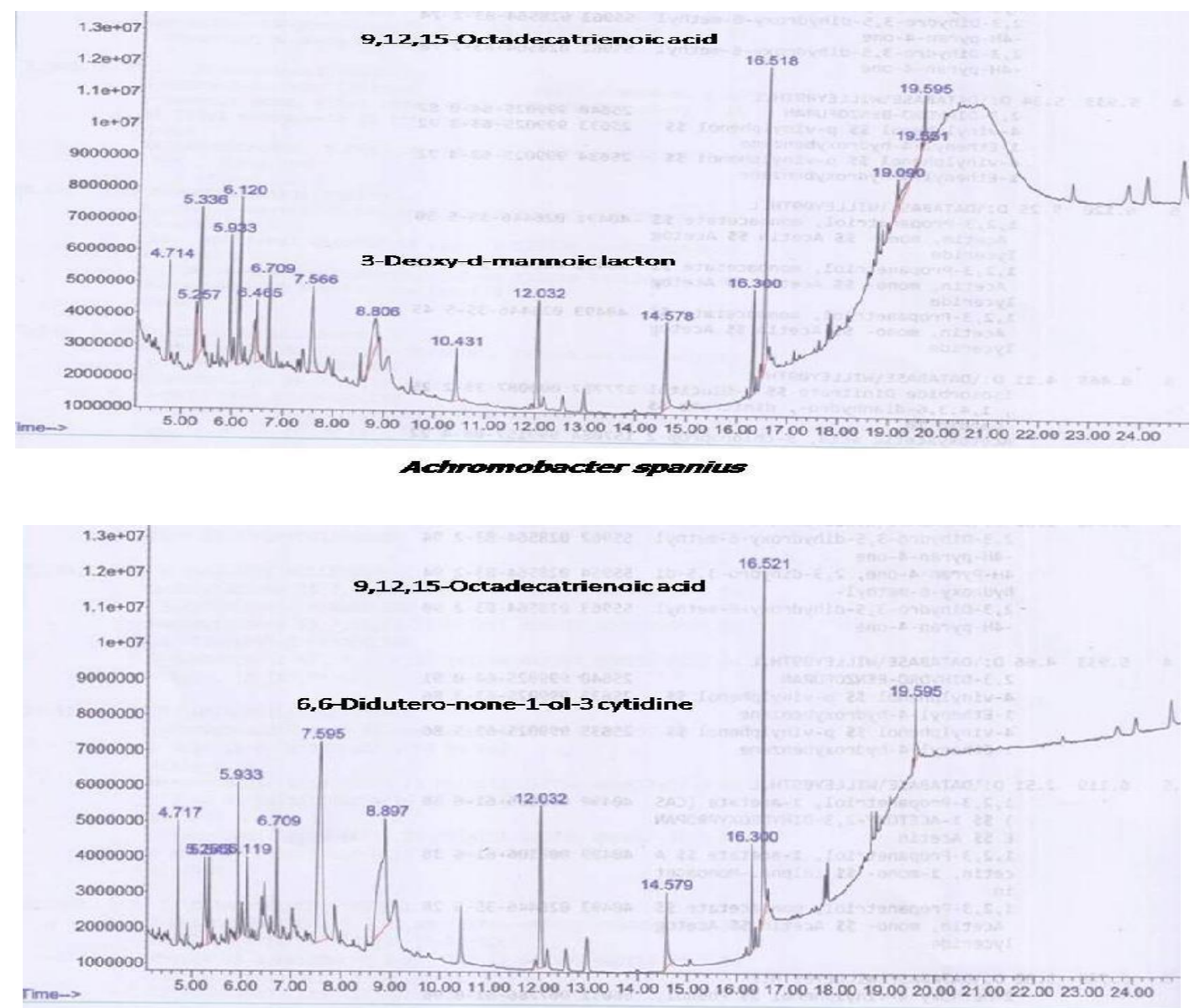

Providencía vermónola

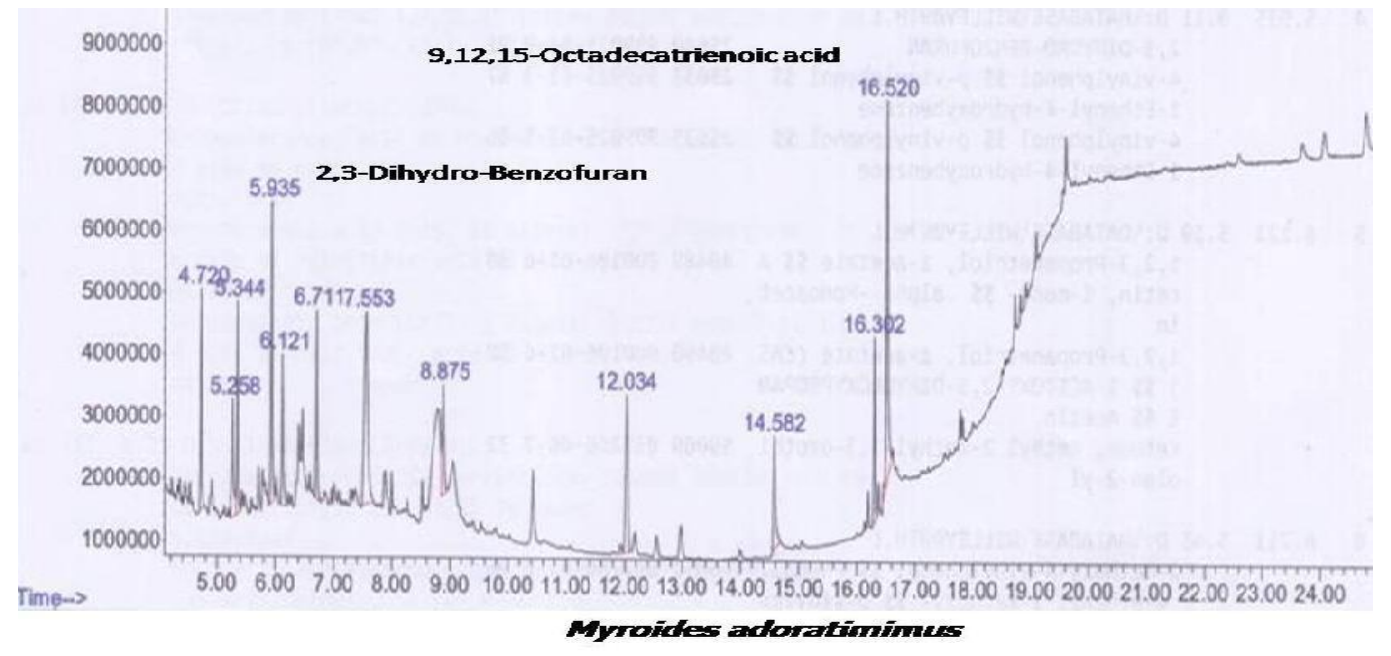




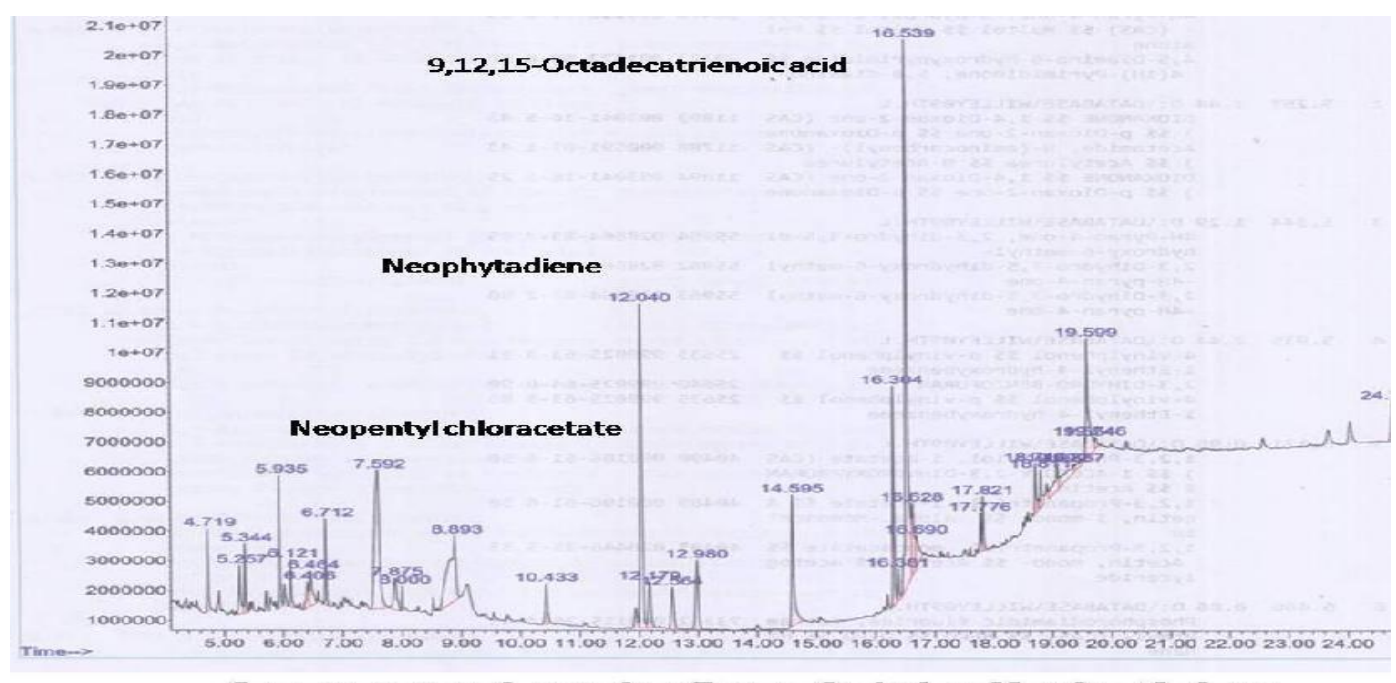

S. mancescens, A. spamius, P. vemicols dan $M$ adoratimimus

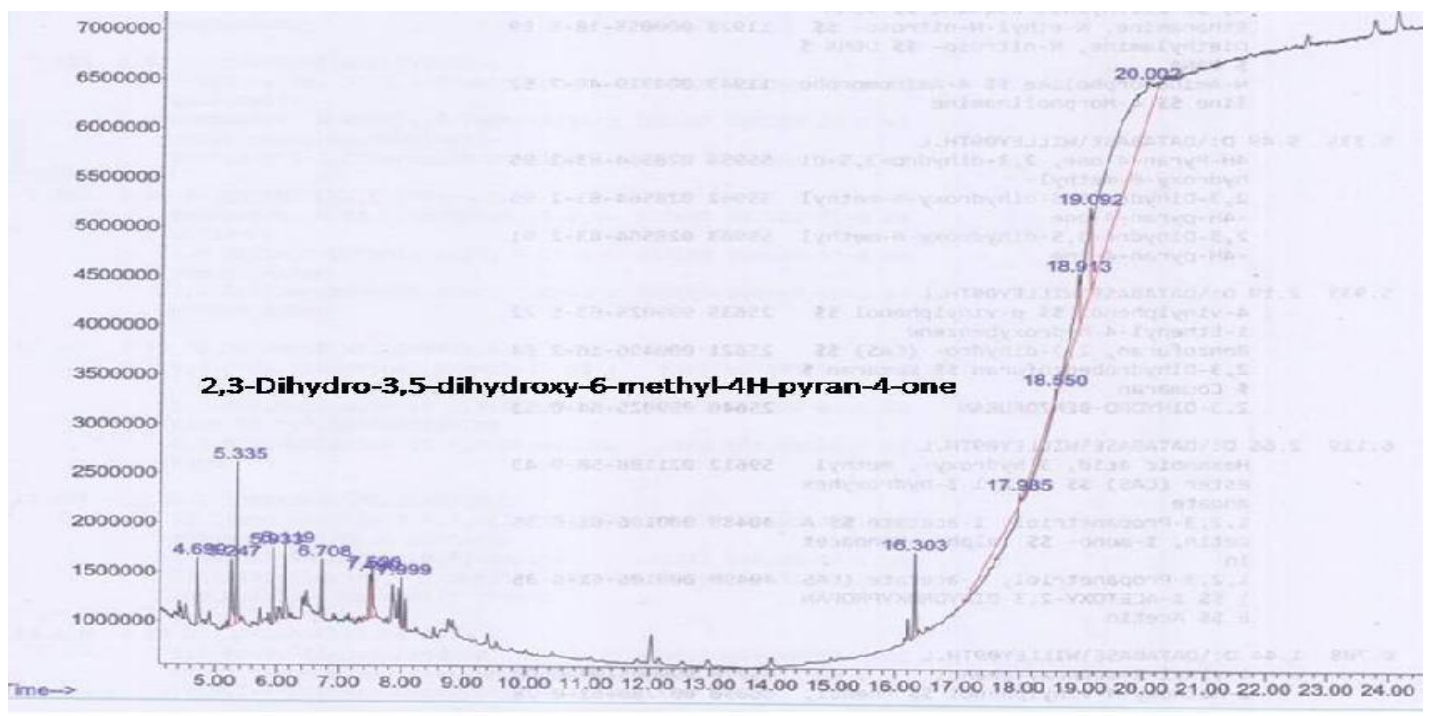

Kontrol (tampa balkteri PGPR)

The plants that are given a combination of PGPR, a type of chemical compound that is almost identical to those that only get the bacteria Serratia marcescens, and Achromobacter spanius. but the higher content of the combination is 9, 12, 15Octadecatrienoic acid, Neophytadiene and Neopentyl chloracetate.

In the control content of active students that appear very little and the percentage is low. In plants that get a combination of bacteria there are 7 types of compounds, Myroides adoratimimus there are 9 types, Providencia vermicola. There are 8 compounds Achromobacter spanius there are 9 types and Serratia marcescens 10.

It is concluded from the results of research on the influence of organic fertilizer in the form of a matrix containing PGPR bacteria, it was found that;

A matrix containing one PGPR bacterium can increase seed germination capacity, and the height of the red rice plant compared to control without PGPR. 
Organic fertilizer in the form of a matrix containing 4 types of bacteria Serratia marcescens, Achromobacter spanius, Providencia vermicola and Myroides adoratimimus can increase the germination capacity of seeds 2 times,

Plant height and number of plant leaves 1.5 times compared to control

Serratia marcescens and Myroides adoratimimus in the flour matrix reduce the number of rice leaves

In terms of stimulating the growth of rice plants. Between PGPR bacteria, it turns out that $A$. spanius and $P$. vermicola bacteria have a fairly good ability to increase the number of tillers in rice plants by 2.5 times the control, and it is expected that later production of brown rice will increase to 2.5 times clay too

In the chromatographic image, it is clear that the compound contained in the control is that the plant without PGPR is given, the amount of its compound is far less than that of rice treated by PGPR bacteria. Rice with PGPR contains 9, 12, 15- Octadecatrienoic acid which is anti-bacterial and anti-fungal, while Neophytadiene and 2-Methoxy-4-vinylphenol can increase plant growth.

\section{References}

Anonim. 2005. Padi beras merah: Pangan bergizi yang terabaikan. Warta penelitian dan pengembangan pertanian. Vol 27. No 4.

Anonim. 2007. Statistik Indonesia. BPS. Jakarta.

Ahsol Hasyim, W. Setiawati, L. S. Marhaeni, L. Lukman, dan A. Hudayya ( 20170).

Bioaktivitas Enam Ekstrak Tumbuhan untuk Pengendalian Hama Tungau Kuning Cabai Polyphagotarsonemus latus Banks (Acari: Tarsonemidae) di
Laboratorium (Bioactivity From Six Plants Extract to Control Chili Pepper Yellow Mites Polyphagotarsonemus latus Banks Under Laboratory Condition). J. Hort. Vol. 27 No. 2, Desember 2017 : 217-230

Brouk, B. 1975. Plants Consumed by Man.Academic Press. London New York, Sanpransisco. Pp. 27-28.

Candra ratna, M.F., 1964. Genetics and Breeding of Rice. Butlerand Tarner Ltd. Frome and London. $334 \mathrm{~h}$.

Damardjati, D.S. 1988. Struktur kandungan gizi beras. hlm. 103165 .

Dalam M. Ismunadji, S. Partohardjono, M. Syam, dan A.Widjono (Ed.). Padi, Buku 1. Pusat Penelitian dan Pengembangan Tanaman Pangan, Bogor.

Didi Suardi, K. 2004. Galur padi beras merah toleran kekeringan, umur genjah, dan protein tinggi. Berita Puslitbangtan. Pusat Penelitian dan Pengembangan Tanaman Pangan. No. 31 December 2004

Potensi beras merah untuk peningkatan mutu pangan. Jurnal Penelitian dan Pengembangan Pertanian. Vol. 24, No. 3, 2005

Gange, G., K.R. Gadhave. 2018. Plant growth-promoting rhizobacteria promote plant size inequality. Scientific reports| (2018) 8:1- 10

IRRI (International Rice Research Institute). 1988. Standard Evaluation System for Rice. IRRI, Los Banos, the Philippines. $14 \mathrm{pp}$.

IRRI. 1995. Evaluation of advanced breeding lines for rice tungro disease resistance. P. 40-42. In IRRI Program report for 1995. Int. Rice Res. Inst, Los Banos, Laguna Philippines Kartina, Mohammad Wahyu Agang, Muhammad Adiwena (2019). Karakterisasi Kandungan Fitokimia Estrak Daun Karamunting (Melastoma malabatchricum L.) Menggunakan 
Metode Gas Chromatography Mass Spectrometry (GC-MS), Biota Vol. 4 (1): 16-23, February 2019

Kochhar, S.1. 1981. Economic Botany in the Tropics. Department Botany University of Delhi. Pp. $76-88$.

Poehlman, J.M. 1977. Breeding Field Crops. The Avi Publishing Company, Inc. Wesport Conecticut.

Santika, A dan Rozakuriati, 2010, Teknik Evaluasi Beras Ketan dan Beras Merah Pada Bererapa Galur Padi Gogo. Buletin Teknik Pertanian, Vol. 15, No. 1: $1-5$

Saputra, A, A.T. Atmadja, , K. Sinarwati (2017). Memaknai konsep keseimbangan antar komponen tri hita karana dalam penganggaran organisasi subak (studi kasus pada subak kaliculuk, desa pakraman dencarik, kecamatan banjar). e- Journal S1 Ak Universitas Pendidikan Ganesha. Vol : 8 No. 2: 2-11

Sudarka, W.; Swara, M. dan D.G. Suardana (1994). Daya Hasil beberapa Varietas

Padi (Oryza sativa L.) local Bali. Majalah Ilmiah Fak. Pertanian UNUD: 52-56

Pertanian Universitaas Udayana, Denpasar. Steponkus, P.L., K.W. Shahan, and J.M. Cutler. (1981). Prinsiples and methode of crops improvement for drought resistance, with emphasis on rice. A paper presented at the special international symposium IRRI. Los Banos. Philippines, 4-5 May1981.

\section{How to cite this article:}

Made Sudana, I., I. Gusti Ngurah Raka and Ni Luh Made Pradnyawathi. 2020. Improvement of Seed Quality and Stimulated the Growth of Brown Rice with Matriconditioning Plus Plant Growth Promoting Rhizobacteria (PGPR) agents in Jatiluih Tourism. Int.J.Curr.Microbiol.App.Sci. 9(08): 2788-2798. doi: https://doi.org/10.20546/ijcmas.2020.908.314 